Gabriela CZAPIEWSKa

Pomeranian University in Słupsk, Poland

\title{
Integration into agricultural producer groups as a manifestation of rural entrepreneurship
}

\begin{abstract}
Entrepreneurship is an integral part of rural development contributing to activation, competitiveness and innovation. One manifestation of rural entrepreneurship is farmers associating into producer groups. The article aims to analyse the determinants of rural entrepreneurship and the functioning of integration processes in agriculture based on Poland's example of agricultural producer groups. The paper presents the theoretical basis for developing collective entrepreneurship in rural areas and agricultural producer groups' current state. The goals and motives for the operation of such producer groups and their benefits are presented. Their formation is the result of integration processes taking place in agriculture, both horizontal and vertical. This study is theoretical, based on the literature and the analysis of legal structures and desk research with secondary sources of information from the Agency for the Restructuring and Modernization of Agriculture. The issues discussed constitute a starting point for further research.
\end{abstract}

Keywords: agriculture; farm producer group; integration; rural entrepreneurship

Received: 12 November 2020

Accepted: 2 March 2021

\section{Suggested citation:}

Czapiewska, G. (2021). Integration into agricultural producer groups as a manifestation of rural entrepreneurship. Przedsiębiorczość - Edukacja [Entrepreneurship - Education], 17(1), 189-202. https://doi.org/10.24917/20833296.171.15

\section{Introduction}

Over the last dozen years, a notion of an economic resource has been re-evaluated. Moreover, the importance of knowledge, creativity, innovation and entrepreneurship has increased. Nowadays, these have become critical factors in the development of enterprises, local environments, regions and the entire national economy (Janasz, 2004; Rak, 2006; Sikorska-Wolak, Krzyżanowska, 2010).

Entrepreneurship, both in agricultural and non-agricultural activities, is an integral part of and condition for rural development. For the most part, it results from a policy of multifunctional rural development. It is treated by many authors as a fundamental 
element in the process of sustainable development in rural areas, as a result of which changes occur in the socio-occupational structure of rural residents, and consequently the scale and effects of unemployment are reduced (Duczkowska-Piasecka, 1998; Hunek, 1995; Kawa, 2005; Rak, 2006).

Developing entrepreneurship among farmers is an essential issue for the entire economy because it generates benefits for the farmer, stimulates greater activity, enhances the imitation of other sectors, and increases agricultural production level. It should be emphasised that in rural environments, entrepreneurship is understood mainly as an activity aimed at earning money.

One manifestation of rural entrepreneurship is the association of farmers into producer groups. According to J. Małysz (1996), the idea of collective action plays an increasingly important role in the modern world and agricultural producer groups are an essential element of the structure of a well-functioning agricultural market. They play essential roles in the agricultural product marketing system, and at the same time, constitute one of the most important ways of gaining a competitive advantage for a farm (Chlebicka, Fałkowski, Wołek, 2008; Lemanowicz, 2004; Hasiński, 2010; Szpon, 2007; Tomczak, 2009; Zawisza, Szkatulski, 2010; Zielińska-Szczepkowska, Kisiel, 2016).

The exploration of these issues aims to analyse the conditions for the development of rural entrepreneurship and the functioning of integration processes in agriculture based on Poland's agricultural producer groups. This exploration is presented as a social science topic, and several research questions are posed:

- What are the foundations of integration processes in agriculture?

- How do agricultural producer groups operate in Poland today?

- What are the goals, motives and effects of these groups?

The research methods used in the evaluation include a comparative and descriptive analysis of the literature, an analysis of legal structures and secondary sources of information, mainly from the Agency for the Restructuring and Modernization of Agriculture (Pol. Agencja Restrukturyzacji i Modernizacji Rolnictwa). In the presentation of the research results, descriptive-analytical, dynamic-comparative and statistical methods are used. For the sake of clarity of interpretation, the statistical material is presented in tabular summaries.

The first part presents the idea of integration processes (definition and historical perspective), while the second outlines the current state and level of development of agricultural producer groups and the goals and benefits of collective activity. The issues discussed will constitute a starting point for further in-depth research.

\section{The idea of agricultural integration: definition and historical approach}

Integration is a concept denoting processes combining the activities of various economic entities. The concept is applied to advanced institutional and material links, while their initial stages are treated more simply as cooperation. There are two primary forms of integration, vertical and horizontal, although sometimes diagonal is discussed (Wyrzykows$\mathrm{ka}, 2004)$. Horizontal integration consists in the gradual joining of interdependent economic units and tightening the links between them, while vertical integration consists in combining independent economic entities from various phases of the production and distribution process (Małysz, 1996; Zalewski, 1989). The main tasks of integration in the food industry, agriculture and trade, are primarily: 
a) increasing the efficiency of production and sales, e.g. by adjusting supply (quantity, quality and place) to the consumers' requirements,

b) reducing risk by guaranteeing the supply of the factors of production to the participants of the integrated process of food production, sale of raw materials and final food products,

c) improving the market position of individual participants (Laskowska, Pieniążek, Zdyb, 1987).

The concept of a producer group is integral to the essence of competitiveness concerning agricultural production and trade in agricultural products. One of the first definitions explaining the essence of agricultural producer groups' functioning was formulated by Małysz (1996: 13-14). In his opinion, "a producer group is an association established on a voluntary and bottom-up basis to sell its produce collectively." K. Kubiak (1997: 25) similarly defines a producer group, "producer organisations (unions, groups) are free associations established to conduct joint activities, most often selling their production". This author also emphasises the entirely voluntary and bottom-up nature of such producer groups. According to W. Boguta (2006: 10), "the modern concept of a producer group is nothing less than cooperatives associating agricultural producers, established for joint sales". E. Pudełkiewicz (1999) emphasises that a producer group's primary task is to carry out joint production of one or more types of goods and, after appropriate preparation and standardisation, sell large batches at favourable prices. This cooperation covers four agricultural activity areas: supply of produce, the production itself, marketing and the common use of machinery.

The legal definition is regulated by the law of 15 September 2000 on agricultural producer groups and their association. It strictly defines the principles and conditions for granting financial aid from public funds related to their organisation and operation. It is based on a long-standing economic tradition of farmer cooperation and defines the rules for organising agricultural producers into groups and their registration procedure. These issues are also regulated from 19 April 2016 by the Ministry of Agriculture and Rural Development based on a list of products and producer groups.

Based on these definitions, it can be concluded that agricultural producers' organisation into groups is entrepreneurial behaviour. Farmers adopt active attitudes to adapt their farms to constantly changing market conditions (Nowak, Gąsior, 2017; Podniesienie konkurencyjności..., 2012; Zawisza, Szkatulski 2010).

Entrepreneurship among farmers is a historical phenomenon. Peasants always displayed certain elements characteristic of entrepreneurship resulting from the specificity of agriculture, family farm or local rural community. In the past, neighbourly help was intensively used to exchange human resources, tools and machines and, with the development of technology and the organisation of agricultural production, more advanced forms of cooperation have developed (Prus, Wawrzyniak, 2010; Sikorska-Wolak, Krzyżanowska, 2010).

Therefore, collective activity in rural areas has a long tradition. The first forms of agricultural cooperation, existing in the period of serfdom, include rural grain stores, loan and savings institutions (so-called carbony), various forms of neighbourly selfhelp, and the introduction of ideas of progress in peasant agriculture, and others (Parzonko, 2010). Cooperation between farmers organised by themselves and not landowners appeared after serfdom was abolished. Usually, these took the form of 
agricultural 'circles' and later, these significantly impacted peasant cooperatives' formation (Janczyk, 1976).

Associations of producer and marketing groups and machine-sharing were among the earliest forms of farmers' organisation, first in the EEC and then in the EU. In Poland, producer groups appeared in the early 1990s in connection with the economic transformation, which had become particularly difficult for agriculture. In the conditions of a command-and-control economy, agricultural producers were assured of their products' sale while the entire sphere of economic life in the countryside and social life was often organised by the commune cooperative (Gołaszewska, 2004; Oleszko-Kurzyna, 2007; Pudełkiewicz, 1999). Between 1990 and 2000, Agricultural Advisory Centres also took active steps to integrate agricultural producers. While the idea of establishing producer groups arose in the early 1990s, it was only at the end of the decade that they became standard. It resulted from an increasing awareness of farmers' necessity to take such action to improve their competitive position on the market.

The emerging groups of agricultural producers started their activities without specific legislation on organising collective forms of management. Only the law on agricultural producer groups and associations at the end of 2000 and the Ministry of Agriculture and Rural Development's relevant regulations made it possible to start the economic process of integration.

\section{The current state and development of agricultural producer groups in Poland}

Agricultural producer groups operate based on the provisions of the EU and national law. The primary acts regulating the essence of the creation and functioning of agricultural producer groups are:

- Regulation No 1305/2013 of the European Parliament and the EU Council of 17 December 2013 on support by the European Agricultural Fund for Rural Development (EAFRD) and repealing Regulation (EC) No 1698/2005;

- Act of 20 February 2015 on supporting rural development with the participation of the European Agricultural Fund for Rural Development under the Rural Development Program for 2014-2020 (Journal of Laws of 2015, item 349, as amended);

- Act of 27 May 2015 on financing the common agricultural policy (Journal of Laws of 2015, item 1130);

- Ordinance of the Ministry of Agriculture and Rural Development of 2 August 2016 on the detailed conditions and procedure for granting payment and return of financial aid for the creation of producer groups and producer organisations covered by the Rural Development Program for 2014-2020 (Journal of Laws of 2016, item 1284);

- Act of 15 September 2000 on agricultural producer groups and their associations and the amendment of other acts (Journal of Laws No. 88, item 983, as amended);

- Ordinance of the Ministry of Agriculture and Rural Development of 19 April 2016 on the list of products and producer groups which may be created, the minimum annual volume of commercial production and the minimum number of members of the group (Journal of Laws of 2016, item 577);

- Regulation of the Ministry of Agriculture and Rural Development of 18 February 2016 on the requirements to be met by a business plan for an agricultural producer group (Journal of Laws of 2016, item 237); 
- Commission Regulation (EU) No 651/2014 of 17 June 2014 declaring certain types of aid compatible with the internal market according to Art. 107 and 108 of the Treaty.

Agricultural producers may collaborate (as a group) in a legal form of their choice, i.e. an association, cooperative or capital company (limited liability or joint-stock). Currently, in Poland, the vast majority are cooperatives (61.7\%), followed by limited liability companies $(34.8 \%)$, and only $3.5 \%$ are associations (Table 1 ). The vast majority of producer groups currently operating have between 5 and 9 members. The essence of companies, cooperatives or other collective forms of running a business is the combination of dispersed (individual) capital and knowledge to achieve expected benefits (Kubiak, 1997; Łobos-Kotowska, 2003; Szalczyk, 1999). In this context, the economic motives for creating such groups of agricultural producers should be considered. In addition to the potential benefits resulting from cooperation, groups can also count on additional financial support from the EU funds (Żochowska, 2016; Warmińska, 2017).

As of the end of September 2020, there were 740 producer groups in Poland (Table 1). It is worth adding that every third group was established in Wielkopolskie Voivodeship (253 producer groups) with the lowest in the Świętokrzyskie (3) and Śląskie (9) voivodeships. It is not the number but the size and specialisation of farms that significantly impact farmers' cooperation.

Table 1. Number and legal forms of agricultural producer groups in Poland

\begin{tabular}{|c|c|c|c|c|c|c|c|}
\hline \multirow{3}{*}{ Voivodeships } & \multicolumn{4}{|c|}{ Agricultural producer groups } & \multicolumn{3}{|c|}{ Legal form } \\
\hline & \multicolumn{2}{|c|}{$\begin{array}{l}\text { total registered } \\
\text { in } 2001-2020^{*}\end{array}$} & \multicolumn{2}{|c|}{\begin{tabular}{|c|} 
as of \\
31 October \\
2020
\end{tabular}} & \multirow[t]{2}{*}{$\begin{array}{l}\text { limited } \\
\text { liability } \\
\text { company }\end{array}$} & \multirow[t]{2}{*}{ cooperative } & \multirow[t]{2}{*}{ association } \\
\hline & number & $\%$ & number & $\%$ & & & \\
\hline Dolnośląskie & 210 & 9.7 & \begin{tabular}{|l|}
66 \\
\end{tabular} & 9.0 & 55 & 9 & 2 \\
\hline Kujawsko-pomorskie & 187 & 8.6 & 45 & 6.1 & 28 & 17 & - \\
\hline Lubelskie & 54 & 2.5 & 14 & 1.9 & 4 & 7 & 3 \\
\hline Lubuskie & 85 & 3.9 & 20 & 2.6 & 12 & 7 & 1 \\
\hline Łódzkie & 120 & 5.6 & 86 & 11.7 & 7 & 79 & - \\
\hline Małopolskie & 27 & 1.3 & 12 & 1.6 & 3 & 6 & 3 \\
\hline Mazowieckie & 120 & 5.6 & 68 & 9.2 & 33 & 26 & 9 \\
\hline Opolskie & 190 & 8.6 & 75 & 10.0 & 32 & 43 & - \\
\hline Podkarpackie & 62 & 2.9 & 22 & 3.0 & 4 & 16 & 2 \\
\hline Podlaskie & 52 & 2.4 & 11 & 1.5 & 6 & 4 & 1 \\
\hline Pomorskie & 105 & 4.9 & 25 & 3.4 & 18 & 7 & - \\
\hline Śląskie & 37 & 1.7 & 9 & 1.2 & 6 & 3 & - \\
\hline Świętokrzyskie & 21 & 0.9 & 3 & 0.4 & 2 & - & 1 \\
\hline $\begin{array}{l}\text { Warmińsko- } \\
\text { mazurskie }\end{array}$ & 120 & 5.6 & 17 & 2.3 & 7 & 10 & - \\
\hline Wielkopolskie & 678 & 31.2 & 253 & 34.2 & 28 & 221 & 4 \\
\hline Zachodniopomorskie & 100 & 4.6 & 14 & 1.9 & 12 & 2 & - \\
\hline Total & 2168 & 100 & 740 & 100 & 257 & 457 & 26 \\
\hline
\end{tabular}

* The data are for the number of agricultural producer groups registered as of 31 October 2020

Source: author based on registers of agricultural producer groups kept by the Agency for Restructuring and Modernization of Agriculture (Agencja Restruktruryzacji i Modernizacji Rolnictwa (2020, 6 September) 


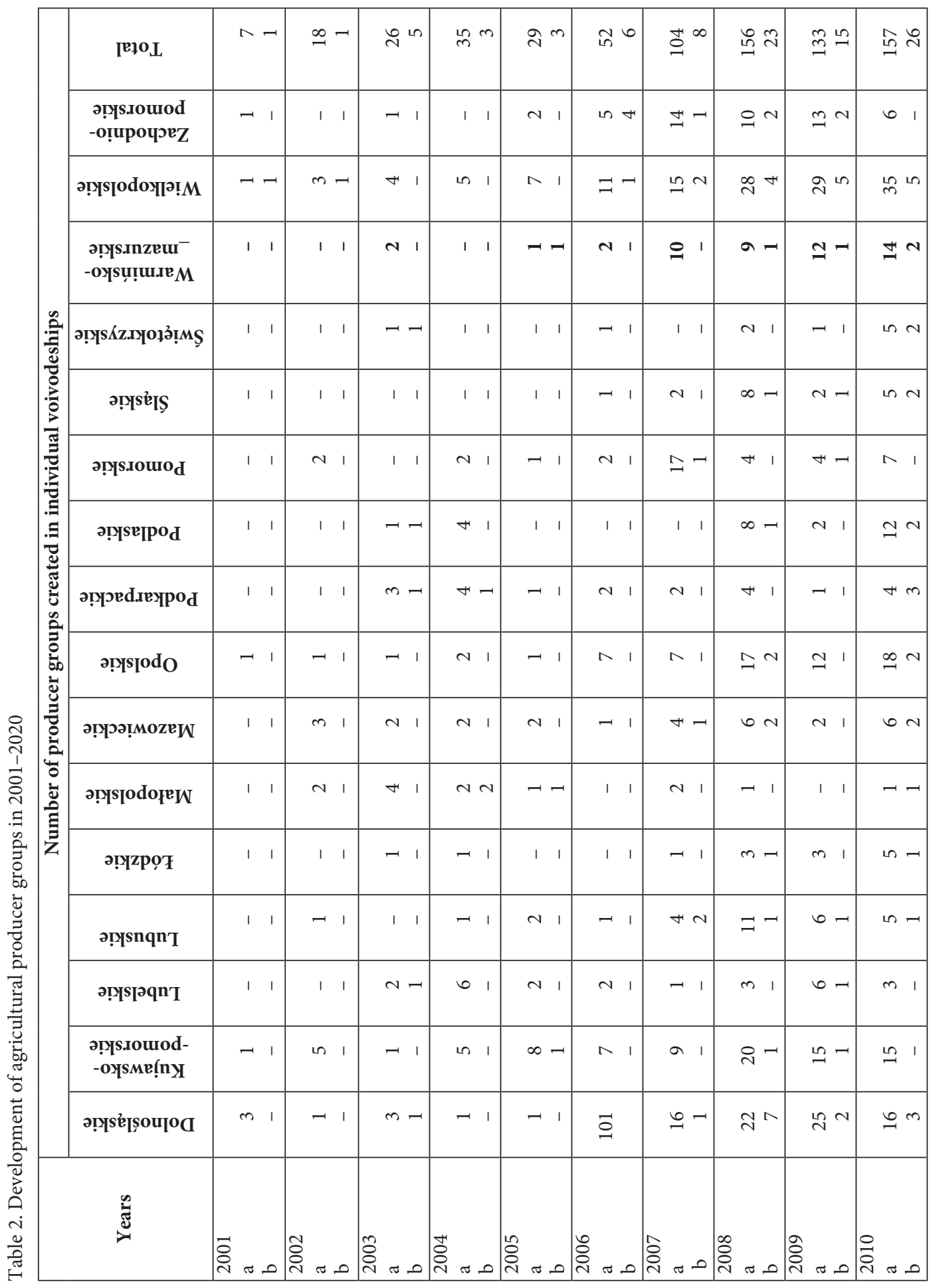




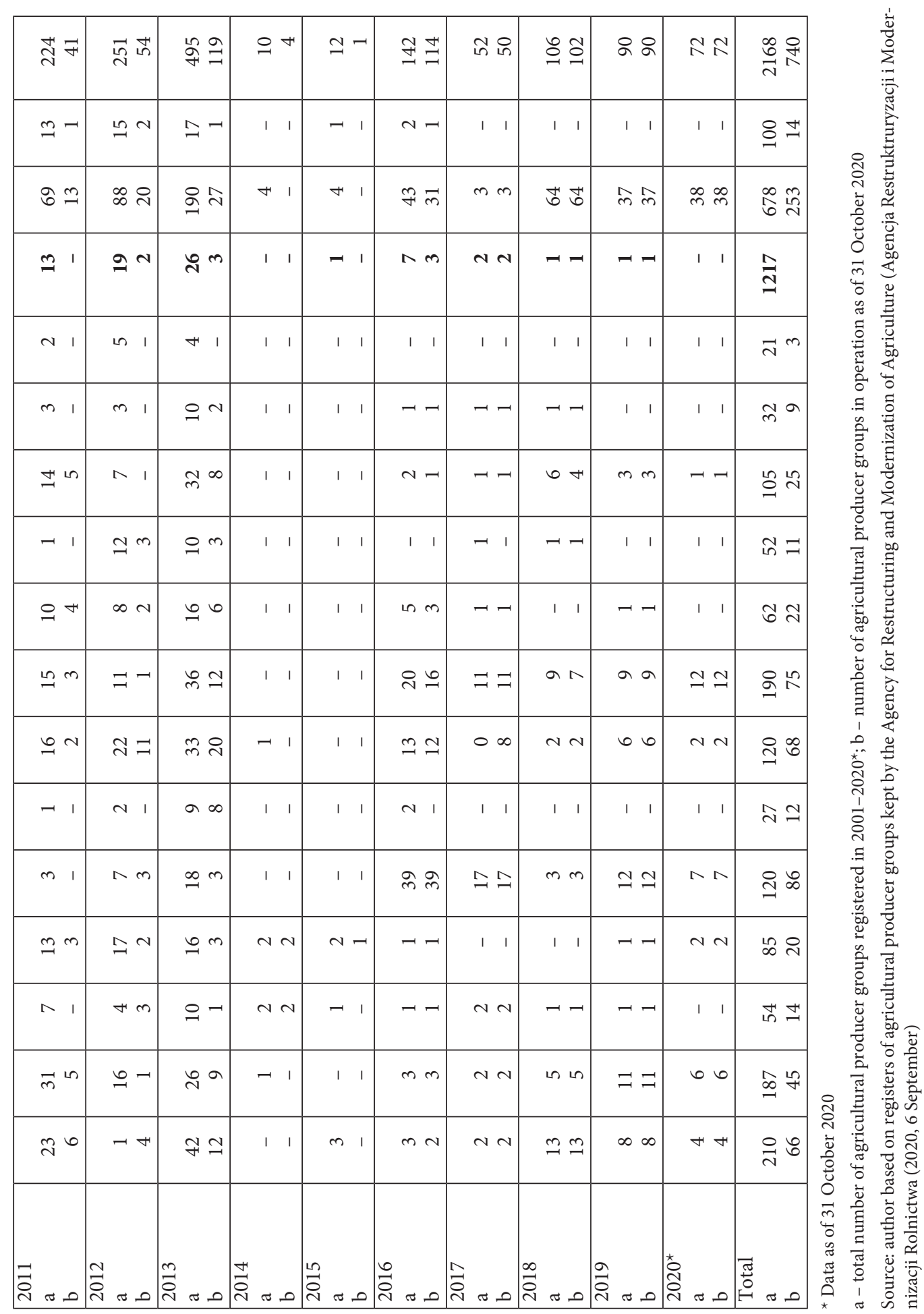


Currently, 737 agricultural producer groups operate in Poland, with producers of pigs (live pigs, piglets, weaners, pork meat - fresh and chilled) constituting $38.6 \%$ and producers of cereals oilseeds, mainly rapeseed, $26.7 \%$ (Table 3). Figures for producers of milk were $10.0 \%$ (cow, sheep, goat milk), poultry (live poultry, fresh and frozen meat) at $8.7 \%$, and cattle (livestock and beef) at $6.9 \%$. Single groups dealt with the cultivation of plants intended for herbal and pharmaceutical production and breeding rabbits.

Table 3. Agricultural producer groups in Poland by produce (as of 31 October 2020)

\begin{tabular}{|c|c|c|c|c|c|c|c|c|c|c|c|c|c|}
\hline \multirow[b]{2}{*}{ Voivodeships } & \multicolumn{13}{|c|}{ Producer groups } \\
\hline & 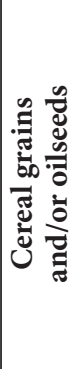 & 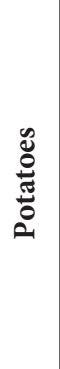 & 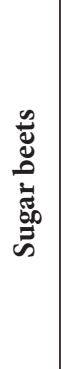 & 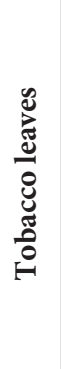 & $\stackrel{\mathscr{0}}{a}$ & 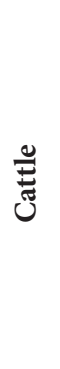 & $\begin{array}{l}\stackrel{E}{\Xi} \\
\stackrel{\Xi}{0}\end{array}$ & 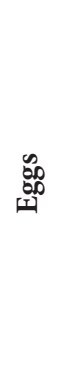 & 兰 & 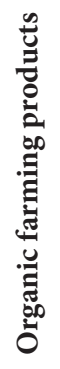 & 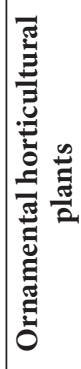 & 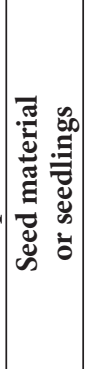 & 离 \\
\hline Dolnośląskie & 46 & 10 & 4 & - & - & 1 & - & - & 1 & 2 & 1 & - & - \\
\hline Kujawsko-pomorskie & 14 & 4 & - & 1 & 14 & 5 & 2 & - & 3 & - & - & 1 & 1 \\
\hline Lubelskie & 3 & - & - & 3 & 7 & - & - & - & - & 1 & - & - & - \\
\hline Lubuskie & 10 & - & - & - & 2 & - & 6 & 1 & 1 & - & - & - & - \\
\hline Łódzkie & 1 & 1 & - & - & 73 & 1 & 2 & 1 & 6 & - & 1 & - & - \\
\hline Małopolskie & 4 & - & - & 2 & 2 & - & 3 & 1 & - & - & - & - & - \\
\hline Mazowieckie & 5 & 1 & - & - & 34 & 1 & 14 & 2 & 11 & - & - & - & - \\
\hline Opolskie & 40 & 2 & 3 & - & 21 & 1 & 5 & 2 & - & - & - & 1 & - \\
\hline Podkarpackie & 12 & 1 & - & 1 & 3 & 1 & 3 & - & 1 & - & - & - & - \\
\hline Podlaskie & 2 & - & - & 1 & 1 & - & 5 & 2 & - & 1 & - & - & - \\
\hline Pomorskie & 5 & 1 & - & - & 8 & 1 & 6 & - & 3 & - & - & 1 & - \\
\hline Śląskie & 2 & - & - & - & 1 & - & 3 & 1 & 2 & - & - & - & - \\
\hline Świętokrzyskie & - & - & - & 1 & - & - & 2 & - & - & - & - & - & - \\
\hline $\begin{array}{l}\text { Warmińsko- } \\
\text { mazurskie }\end{array}$ & 6 & - & - & - & 3 & 2 & 5 & - & 1 & - & - & - & - \\
\hline Wielkopolskie & 33 & 3 & 9 & - & 118 & 39 & 7 & 1 & 42 & - & - & - & 1 \\
\hline Zachodniopomorskie & 12 & - & - & - & - & $\begin{array}{ll}- \\
\end{array}$ & 1 & - & 1 & - & - & - & - \\
\hline Total & 195 & 23 & 16 & 9 & 287 & 52 & 64 & 11 & 72 & 4 & 2 & 3 & 2 \\
\hline
\end{tabular}

Source: author based on registers of agricultural producer groups kept by the Agency for Restructuring and Modernization of Agriculture (Agencja Restruktruryzacji i Modernizacji Rolnictwa, 2020, 6 September)

Goals, motives and effects of the collective activity of agricultural producers

Experience to date shows that collective economic activity in agriculture is conditioned by multiple endogenous factors (which describe farmers and their farms) and exogenous factors (impulses coming from immediate and more distant surroundings). 
When deciding on group entrepreneurship, farmers are most often guided by motives to achieve a stable situation in complex farming conditions or even maintain an association for the future. Such a situation was found in breakthrough moments. One of them was the economic transformation when the liberation of agricultural markets brought large fluctuations in prices for agricultural produce and means of production, problems with selling farm produce, and maladjustment in terms of quality and quantity to the requirements of agri-food enterprises. Another one was Poland's accession to the EU which forced agricultural producers to introduce several changes to adjust to the EU requirements (Kania, Bogusz, 2009; Krzyminiewska, 2006; Parzonko, 2010).

The main goal of each group of producers (Table 4) is to introduce products from the farms of its members to the market, while the specific rules of the group's operation allow for payment in proportion to the level of shared services used (Kania, 2008; Krzyżanowska, 2001; Wiatrak, 2006; Zawisza, Szkatulski, 2010; see Table 4). For economic reasons, two general goals can be formulated: striving to achieve long-term economic benefits (increase in income) for individual agricultural producers through collective activities and the use of flat-rate financial aid from the EU funds depending on sales volume (Goszka, 2010; Siemiński, Žukovskis, Senkus, 2018).

Among the crucial goals for creating producer groups, the following need to be mentioned: establishing cooperative groups to take over various links of the technological process using the experience of individual producers; conducting joint investments that usually exceed the capabilities of a single producer; performing integrated agricultural production (in terms of area, animal breeds, crop varieties, and others); as well as creating marketing channels integrated with agri-food processing enterprises (Boguta, 2006; Chorób, 2010; Mierzwa, 2007).

The main effects of agricultural group entrepreneurship include increasing the allocation of resources, reducing production costs thanks to economies of scale and scope, and obtaining greater bargaining power by consolidating the efforts of all producers (Makarski, 2000; Halicka, Rejman, 2001; Turski, Witosław, 2004; Chlebicka, 2011; Promocja tworzenia... 2011). Horizontal integration in agriculture also contributes to better use of available resources and increases human capital. Farm owners, acting as a group, have easier access to market and scientific information, external financing sources and greater investment opportunities (Zawisza, 2010; Nowak, Gąsior, 2017; Kozłowska-Burdziak, Przygodzka, 2019).

Table 4. Goals and effects of agricultural producer groups

\begin{tabular}{|l|l|}
\hline Objectives of agricultural producer groups & Effects of agricultural producer groups \\
\hline - jointly selling products or groups of farm & - limiting the number of intermediaries \\
produce of the group members & - a single manager \\
- creating cooperative groups that take & - reducing the costs of agricultural \\
over various links of the technological & production, \\
process, using the experience of individual & - having a larger and uniform batch of high- \\
producers & quality goods \\
- improvement of management efficiency & - joint (wholesale) purchase of production \\
- integrated agricultural production (in & means cheaper fertilisers, plant protection \\
terms of area, breeds, varieties etc.) & chemicals, transport, etc. \\
- adapting agricultural production to & - joint preparation of appropriate batches of \\
market conditions & products (storage, drying, packaging and \\
& labelling) \\
\hline
\end{tabular}


- joint supply of working assets for current agricultural production

- organising collective storage activities

- supply concentration

- increasing farmers' income by reducing costs, planning and preparing large, homogeneous batches of high-quality products

- creating marketing channels integrated with agri-food processing enterprises

- natural environment preservation
- building permanent cooperative relations with consumers ready to pay a higher price for products with established quality standards, ensuring continuity of deliveries of a specific batch size

- partnership cooperation, resulting in the strengthening of market position and better monitoring (access to information)

- joint investments (capital, loans, machines, warehouses, cold stores, etc.) and the introduction of new technologies

- conducting training and marketing activities (joint product promotion)

- exchange of experience and market information

- spreading risk among all group members, solving problems together and the use of consultants

Source: author based on Chlebicka (2011), Halicka, Rejman (2001), Promocja tworzenia... (2011), Krajowa Sieć Obszarów Wiejskich (2020)

\section{Conlusions}

Entrepreneurship in rural areas is a significant factor in their socio-economic development, triggering many initiatives and activity for the inhabitants. One aspect is the integration of farm owners into groups of agricultural producers. In Poland, their dynamic development took place after integration with the EU, resulting from increased competition on the European market, to which the fragmented Polish agriculture was subjected, and financial aid for the functioning and formal registering of producer groups. The entrepreneurial attitudes of farmers are currently supported by funds from the Common Agricultural Policy, which included Polish agriculture after integration in 2004. It took place under the Rural Development Plan in the programming period covering the years 2004-2006 and then continued under Rural Development Programs for 2007-2013 and 2014-2020.

The formation of agricultural producer groups results from ongoing integration in agriculture, both horizontal and vertical. Therefore, the market economy's progressive development forces agricultural producers to take action aimed at horizontal integration between the producers themselves and integration with other agribusiness institutions supporting agriculture.

Economic factors are the most critical element when producers make decisions about collective activities. Horizontal integration of farmers, based on joint action, makes it possible to meet the market economy's challenges; however, despite the clear benefits of horizontal integration in agriculture, there has been a visible decline in the number of agricultural producer groups. One important reason is the reluctance of the rural population to undertake new initiatives, resulting from a lack of legal knowledge. The issue of farmers' reluctance to associate into producer groups, especially in recent years, or resignation from such a form of cooperation, requires in-depth research and systemic solutions under the Common Agricultural Policy for 2021-2027. It is necessary to introduce new, 
more favourable and appropriate legal solutions (especially for producers with small and medium production potential), greater financial support and a guarantee of assistance in the integration process. The collective activity is of particular importance in a long-term perspective because, as research shows, it favours the implementation of new production technologies, improvement of product quality and the economic effects of farming, as well as strengthening the market position of individual entities (Kozłowska-Burdziak, Przygodzka, 2019; Szpon, 2004, 2007; Warmińska, 2017; Zawisza, Szkatulski, 2010).

The future of agricultural producer groups may be in closer cooperation and with established unions of such groups. With a more significant production potential, the rational direction of a group's activity would be to develop primary processing, either through their plants or through outsourcing. It is to be hoped that competition from the EU agriculture, combined with significant financial aid in coming years, will also stimulate new producer groups in Poland.

The functioning of agricultural producer groups is of fundamental importance for further developing the entire agribusiness sphere. Insufficient development of joint forms of management reduces agriculture's competitiveness and limits rural areas and agriculture's further development. Current conditions for this sector's development require farmers to be more economical, exceeding current standards. The analyses in this work converge with other authors' research and constitute a platform for further exploring the integration issues in agriculture.

\section{References}

Agencja Restruktruryzacji i Modernizacji Rolnictwa. (2020, 6 September). https://www.arimr.gov.pl

Boguta, W. (ed.). (2006). Organizacja i funkcjonowanie grup producentów rolnych. Warszawa: Krajowa Rada Spółdzielcza.

Chlebicka, A., Fałkowski, J., Wołek, T. (2008). Powstawanie grup producentów rolnych a zmienność cen. Warszawa: FAPA.

Chlebicka, A. (2011). Czynniki wpływające na sukces grup producentów rolnych. Journal of Agribusiness and Rural Development, 4(22), 31-39.

Chorób, R. (2010). Marketingowe grupy producentów rolnych jako determinanta rozwoju obszarów wiejskich. Wieś i Rolnictwo, 2(147), 158-172.

Duczkowska-Piasecka, M. (1998). Przedsiębiorczość na wsi. In: A. Woś (ed.), Encyklopedia agrobiznesu. Warszawa: Fundacja Innowacja, 634-639.

Gołaszewska, B. (2004). Szanse i bariery funkcjonowania grup producentów rolnych w Polsce. Roczniki Naukowe Stowarzyszenia Ekonomistów Rolnictwa i Agrobiznesu, 6(1), 55-61.

Goszka, W. (2010). Prawno-ekonomiczne uwarunkowania działalności grup producentów rolnych. In: S. Zawisza (ed.), Perspektywy rozwoju grup producentów rolnych - szanse i zagrożenia. Bydgoszcz: Wydawnictwo UTP, 39-47.

Halicka, E., Rejman, K. (2001). Przedsiębiorczość rolników wobec integracji z Unią Europejską - tworzenie grup producentów rolnych. In: K. Gutkowska, J. Ozimek (ed.), Rozwój przedsiębiorczości wiejskiej w perspektywie integracji z Uniq Europejską. Warszawa: Wydawnictwo SGGW, 38-43.

Hasiński, W. (2010). Integracja pozioma gospodarstw rolnych w Polsce ze szczególnym uwzględnieniem województwa dolnośląskiego. In: S. Ciok, P. Migoń (ed.), Przekształcenia struktur regionalnych aspekty społeczne, ekonomiczne i przyrodnicze. Wrocław: Wydawnictwo UW, 349-359.

Hunek, T. (1995). Drobna przedsiębiorczość (small business) na terenach wiejskich. Systemowe uwarunkowania rozwoju. Wieś i Rolnictwo, 4, 126-138. 
Janasz, W. (red.). (2004). Innowacja w rozwoju przedsiębiorczości w procesie transformacji. Warszawa: Difin.

Janczyk, T. (1976). Spółdzielczość polska - geneza, rozwój, perspektywy. Warszawa: Zakład Wydawnictw CRS.

Kania, J. (2008). Razem możemy więcej, czyli jak wspólnie działać w grupach producentów rolnych. Zagadnienia Doradztwa Rolniczego, 4, 16-28.

Kania, J., Bogusz, M. (2009). Społeczno-ekonomiczne aspekty funkcjonowania grup producentów rolnych w województwie małopolskim. In: S. Zawisza (ed.), Rozwój przedsiębiorczości i zespołowej działalności gospodarczej $w$ rolnictwie $w$ świetle integracji $z$ Uniq Europejską. Bydgoszcz: Wydawnictwo UTP, 181-197.

Kawa, M. (2005). Grupy producentów rolnych jako forma przedsiębiorczości zespołowej. Rzeszów: Wydawnictwo UR.

Kozłowska-Burdziak, M., Przygodzka, R. (2019). Grupy producentów rolnych - szanse i bariery rozwoju. Białystok: Wydawnictwo UwB.

Krajowa Sieć Obszarów Wiejskich. (2020, 6 September). http://ksow.pl/grupy-producentow-rolnych. html

Krawczyk, P. (2007). Integracja pozioma w rolnictwie. In: R. Jabłonka (ed.), Grupy producentów w wybranych gałęziach produkcji rolniczej. Siedlce: Wydawnictwo AP, 10-29.

Krzyminiewska, G. (2006). Społeczno-ekonomiczne determinanty rozwoju przedsiębiorczości wiejskiej. In: A. M. Rak (ed.). Przedsiębiorczość w rozwoju obszarów wiejskich. Siedlce: Wydawnictwo AP, $13-22$.

Krzyżanowska, K. (2001). Grupy producenckie jako forma współpracy gospodarstw rodzinnych. In: Rola i miejsce gospodarstw rodzinnych w systemie rolnictwa polskiego i Europejskiego. Bydgoszcz: Wydawnictwo UTR, 96-108.

Kubiak, K. (1997). Formy organizacyjno-prawne jednostek gospodarczych działajacych $w$ rolnictwie i ogrodnictwie oraz organizacje producentów. Warszawa: COBRO, 10-25.

Laskowska, I., Pieniążek, K., Zdyb, E. (1987). Formy integracji przemysłu spożywczego i rolnictwa w niektórych krajach Europy. Ekspertyza. Warszawa: IERiGŻ.

Lemanowicz, M. (2004). Grupy producenckie i marketingowe i ich wpływ na pozycję konkurencyjną rolników na rynku. Acta Scientiarum Polonorum, Oeconomia, 3(1), 103-115.

Łobos-Kotowska, D. (2003). Prawna forma organizacji i funkcjonowanie grup producentów rolnych. Studia Iuridica Agraria, 2, 99-110.

Małysz, J. (1996). Procesy integracyjne w agrobiznesie. ABC integracji. Poznań: CDiEwR.

Makarski, S. (2000). Integracja pionowa w agrobiznesie (ze szczególnym uwzględnieniem rolnictwa). In: A.P. Wiatrak (ed.), Kierunki i możliwości zmian w organizacji gospodarstw i przedsiębiorstw rolniczych $w$ procesie modernizacji obszarów wiejskich $w$ Polsce. Warszawa: Wydawnictwo SGGW, $167-175$.

Mierzwa, D. (2007). Aktualny stan i perspektywy rozwoju zespołowych form gospodarowania na wsi. Zagadnienia Doradztwa Rolniczego, 3/4, 49-59.

Nowak, A., Gąsior, R. (2017). Integracja pozioma producentów rolnych - możliwości i bariery. Annales Universitatis Mariae Curie-Skłodowska, LI(1), 63-73.

Oleszko-Kurzyna, B. (2007). Postawy rolników wobec grup producentów rolnych. Annales Universitatis Mariae Curie-Skłodowska, XLI(41), 161-176.

Otrębowska, K. (2017; 2020, 1 September). Podstawy prawne funkcjonowania grup producentów rolnych. Retrieved from: http://grupyproducentow.pl/artykuly/a_38,podstawy-prawne-funkcjonowania-grup-producentow-rolnych

Parzonko, A.J. (2010). Rozwój przedsiębiorczości zespołowej na wsi oraz psychologiczne i ekonomiczne aspekty funkcjonowania grup producentów rolnych. In: K. Krzyżanowska (ed.), Przedsiębiorczość na obszarach wiejskich. Stan i perspektywy rozwoju. Warszawa: Wydawnictwo SGGW, 103-123.

Piasecki, B. (1999). Ekonomika i zarządzanie mała firma. Warszawa: PWN. 
Podniesienie konkurencyjności gospodarstw rolnych poprzez zrzeszanie się rolników ze szczególnym uwzględnieniem formy spółdzielczej. (2012). Warszawa: Krajowa Rada Spółdzielcza.

Promocja tworzenia grup producentów rolnych. (2011). Warszawa: MRiRW.

Prus, P., Wawrzyniak, B.M. (2010). Rola Unii Europejskiej w rozwoju grup producentów rolnych w Polsce. In: S. Zawisza (ed.), Perspektywy rozwoju grup producentów rolnych - szanse i zagrożenia. Bydgoszcz: Wydawnictwo UTP, 49-58.

Pudełkiewicz, E. (1999). Spółdzielczość wiejska. Warszawa: FAPA.

Rak, A.M. (red.) (2006). Przedsiębiorczość w rozwoju obszarów wiejskich. Siedlce: Wydawnictwo AP.

Rozporzadzenie Parlamentu Europejskiego i Rady (UE) nr 1305/2013 z dnia 17 grudnia 2013 roku w sprawie wsparcia rozwoju obszarów wiejskich przez Europejski Fundusz Rolny na rzecz Rozwoju Obszarów Wiejskich (EFRROW) i uchylającego rozporządzenie Rady (WE) nr 1698/2005 (Dz.U. UE, 2013, L. 347/487)

Rozporządzenie Ministra Rolnictwa i Rozwoju Wsi z dnia 18 lutego 2016 r. w sprawie wymagań, jakie powinien spełniać plan biznesowy grupy producentów rolnych, $\$ 1$ ust. 1 pkt 8 (Dz.U. z 2016 r., poz. 237).

Rozporzadzenie Ministra Rolnictwa i Rozwoju Wsi z dnia 2 sierpnia 2016 roku w sprawie szczegółowych warunków i trybu przyznawania, wypłaty oraz zwrotu pomocy finansowej $w$ ramach działania „Tworzenie grup producentów i organizacji producentów” objętego Programem Rozwoju Obszarów Wiejskich na lata 2014-2020 (Dz.U. z 2016 r., poz. 1284).

Siemiński, P., Žukovskis, J., Senkus, P. (2018). Regional Diversification of the Effects of Support for Agricultural Producer Groups in Poland. Zeszyty Naukowe Uniwersytetu PrzyrodniczoHumanistycznego w Siedlcach. Administracja i Zarządzanie, 46, 119, 35-42.

Sikorska-Wolak, J., Krzyżanowska, K. (2010). Przedsiębiorczość w ujęciu teoretycznym i w praktyce. In: K. Krzyżanowska (ed.), Przedsiębiorczość na obszarach wiejskich. Stan i perspektywy rozwoju. Warszawa: Wydawnictwo SGGW, 39-57.

Szalczyk, Z. (1999). Dlaczego grupy producenckie. Poradnik Gospodarski, 2, 4-7.

Szpon, J. (2007). Integracja pozioma w rolnictwie jako szansa poprawy wyników ekonomicznych produkcji rolnej. Folia Universitatis Agriculturae Stetinensis. Oeconomica, 252(46), 67-74.

Tomczak, P. (2009). Grupy producentów rolnych jako nowe formy zespołowego działania na polskiej wsi. Studia Obszarów Wiejskich, XVII, 201-212.

Turski, J., Witosław, K. (2004). Grupy producentów rolnych polskiego rolnictwa. Biuletyn Informacyjny $A R R, 2(152), 62-65$.

Ustawa $z$ dnia 20 lutego 2015 roku o wspieraniu rozwoju obszarów wiejskich $z$ udziałem środków Europejskiego Funduszu Rolnego na rzecz Rozwoju Obszarów Wiejskich w ramach Programu Rozwoju Obszarów Wiejskich na lata 2014-2020 (Dz.U. z 2015 r., poz. 349 z późn. zm.).

Ustawa z dnia 27 maja 2015 roku o finansowaniu wspólnej polityki rolnej (Dz.U. z 2015 r., poz. 1130).

Uchwała Nr 163 Rady Ministrów z dnia 25 kwietnia 2012 r. w sprawie przyjęcia „Strategii zrównoważonego rozwoju wsi, rolnictwa i rybactwa" na lata 2012-2020. (Monitor Polski. Dz.U. Rzeczypospolitej, 2012, poz. 839).

Ustawa $z$ dnia 11 września 2015 r. o zmianie ustawy o grupach producentów rolnych i ich związkach oraz o zmianie innych ustaw oraz ustawy o wspieraniu rozwoju obszarów wiejskich $z$ udziałem środków Europejskiego Funduszu Rolnego na rzecz Rozwoju Obszarów Wiejskich w ramach Programu Rozwoju Obszarów Wiejskich na lata 2014-2020 (Dz.U. poz. 1888).

Warmińska, A. (2017). Czynniki motywujące członków grup producentów rolnych do wzrostu zaangażowania w działania podejmowane przez grupę. Zarzadzanie, Zeszyty Naukowe Politechniki Częstochowskiej, 25, 41-49.

Wiatrak, A.P. (2006). Grupy producentów rolnych - istota działania i zarządzania nimi. Roczniki Naukowe Stowarzyszenia Ekonomistów Rolnictwa i Agrobiznesu, VIII(4), 361-365.

Wyrzykowska, B. (2004). Rodzaje powiązań integracyjnych w agrobiznesie. Ekonomika i Organizacja Gospodarki Żywnościowej. Zeszyty Naukowe Szkoły Głównej Gospodarstwa Wiejskiego, 53, 57-76. 
Zalewski, A. 1989. Problemy gospodarki żywnościowej w Polsce. Warszawa: PWN.

Zawisza, S., Szkatulski, M. (2010). Znaczenie grup producentów rolnych $w$ rozwoju wsi i rolnictwa. In:

S. Zawisza (ed.), Perspektywy rozwoju grup producentów rolnych - szanse i zagrożenia. Bydgoszcz: Wydawnictwo UTP, 9-21.

Zielińska-Szczepkowska, J., Kisiel, R. (2016). Zrzeszanie się producentów rolnych jako przykład współdziałania w sektorze rolnictwa - doświadczenia wybranych krajów członkowskich Unii Europejskiej. Problemy Rolnictwa Światowego, 16(XXXI/2), 372-386.

Żochowska, A. (2016). Nowe warunki udzielania wsparcia finansowego grupom producentów rolnych w ramach Wspólnej Polityki Rolnej. Studia Iuridica Agraria, 14, 401-418.

Gabriela Czapiewska, PhD, assistant professor, Pomeranian University in Slupsk, Institute of Socio-Economic Geography and Tourism. Research issues and publication themes concentrate on agriculture's problems and the multifunctional and sustainable development of rural areas. The author's research also covers issues related to regional geography.

ORCID: https://orcid.org/0000-0002-5638-9831

\section{Address:}

Akademia Pomorska w Słupsku

Instytut Geografii Społeczno-Ekonomicznej i Turystyki

ul. Partyzantów 27

76-200 Słupsk, Polska

e-mail: gabriela.czapiewska@apsl.edu.pl 